University at Buffalo School of Law

Digital Commons @ University at Buffalo School of Law

\title{
Stability, Integration and Political Modalities: Some American Reflections on the European Project After the Financial Crisis
}

\author{
David A. Westbrook \\ University at Buffalo School of Law, dwestbro@buffalo.edu
}

Follow this and additional works at: https://digitalcommons.law.buffalo.edu/book_sections

Part of the International Trade Law Commons, and the Law and Economics Commons

\section{Recommended Citation}

David A. Westbrook, Stability, Integration and Political Modalities: Some American Reflections on the European Project After the Financial Crisis in Making Transnational Law Work in the Global Economy: Essays in Honour of Detlev Vagts 453 (Pieter H. F. Bekker, Rudolf Dolzer \& Michael Waibel, eds., Cambridge University Press 2010)

This material has been published in Making Transnational Law Work in the Global Economy: Essays in Honour of Detlev Vagts edited by Pieter H. F. Bekker, Rudolf Dolzer \& Michael Waibel. This version is free to view and download for personal use only. Not for re-distribution, re-sale or use in derivative works. (c) Cambridge University Press 2010.

\section{IN COPYRIGHT}

This Book is brought to you for free and open access by the Faculty Scholarship at Digital Commons @ University at Buffalo School of Law. It has been accepted for inclusion in Contributions to Books by an authorized administrator of Digital Commons @ University at Buffalo School of Law. For more information, please contact lawscholar@buffalo.edu. 


\section{Stability, integration and political modalities: some American reflections on the European project after the financial crisis}

DAVID A. WESTBROOK

To those of us concerned with transnational law, and especially the role of German law on the global stage, it does not need saying that Professor Detlev Vagts is highly deserving of that Germanic and traditional scholarly honour, a Festchrift. (In this context, 'does not need saying' of course means 'should be said repeatedly'.) We all owe Detlev Vagts, and as a Germanic traditionalist, I would be delighted to contribute to this volume on general principle, even if I did not know the man. But I also have personal reasons for wanting to honour Professor Vagts: he taught the basic course in corporations to generations of students at Harvard Law School. In addition, Vagts was one of the advisors to the Ford Fellows Program, which was designed to foster international law teachers. After being one such student and one such fellow, in due course I became a teacher of international and corporation law, so I owe Vagts a double debt of professional gratitude. And, as with so many other young (or once young) scholars, Vagts has been cordially supportive of my efforts to find my way in the academy, for which I am most grateful.

Such things said, however, there is another reason I am happy to have the chance to contribute to this Festschrift. A certain delicacy is called for here, especially since writing for Vagts carries me halfway back to Harvard, where such things are taken so seriously. But enough beating

* Some of the thinking in this chapter was first expressed in the context of 'policy roundtables' hosted by the European Commission's Bureau of European Policy Advisers (BEPA). My thanks to Vitor Gaspar, and to the BEPA, for inviting me to participate in these transnational intellectual exchanges, which I am sure Vagts would have enjoyed. Thanks also to Pierre d'Argent, Jean-Marc Gollier, Rosa Lastra and Dirk Schoenmaker for very helpful comments. The infelicities and outright mistakes are my own. 
around the bush: I was not the strongest student in that corporations course. Actually, I was some distance away from the strongest student. In fact, I could not see her. I have excuses, of course, but the bottom line is that this chapter is a chance not only to honour a dedicated scholar and devoted teacher, but also for academic redemption.

I do not seriously propose that the financial policy community adopt the flippant Christian stance with which I am playing here. But this chapter is written as we (appear to) have hit the bottom of the worst financial crisis since the Great Depression. Even if the bottom has been reached, the damage done around the world has been great, and it will take many years to recover. Here in the United States, it is quite possible that some things - a measure of trust in certain key institutions, a sense of workingman's possibility, what might be called republican spirit, perhaps even a degree of national creditworthiness - have passed from the scene. In Europe, the financial crisis revealed not only substantial weaknesses in the internal market, but also, and more troublingly, cracks in the European project itself. Policies and institutions that seemed essentially 'European' in scope and orientation during good times were revealed to be, when conditions got tough, fundamentally national after all. Bluntly, after the crisis it appears that the process of integration begun after the Second World War may not have progressed as far as many believed not so long ago.

It is not my purpose, especially not in the pages of a Festschrift, to cast blame. But the fact remains that financial policy on both sides of the Atlantic (and elsewhere) failed in a host of ways; the 'entire edifice' collapsed, as former Chairman of the US Federal Reserve, Alan Greenspan, put it to the US Congress. The failure of a raft of financial policies - to say nothing of the complete absence of collective consideration of a host of topics which proved expensively relevant in the years 2007-09 - ought to give pause to those of us who profess to teach finance. Perhaps we have no need for redemption, but with one in four American children on food stamps and more than the suspicion that the Great Recession was caused by overweening faith in finance itself, I am not so sure. The matter is worth careful thought. Surely, however, the tendency of financial elites to congratulate themselves on navigating 'the tsunami' on surviving the massive failure of their own policies - is misplaced and, in light of the damage done, more than a little unseemly.

I should immediately point out that Vagts came of intellectual age when the currents which engendered the latest crisis were mere rivulets. In class, he had none of the narrow-minded certainty which marked the 
heyday of law and economics. His view of the business world and the lawyer's role in it was always more nuanced. Even in the basic course on corporations, Vagts tried to instil an understanding that things were often done differently, elsewhere (an attitude taught by comparative law), and had been done differently, even here, at other times (an attitude taught by history). More deeply still, Vagts was quite aware of human fallibility, and its sometimes awful potential - he freely admitted to being marked by the Second World War. So had we as a nation kept some of these lessons in mind, would our economy be in better shape than it is today? Perhaps, but there are reasons we speak of manias - and even Newton got caught up in the South Seas Bubble.

But it also may be hoped that we learn from crises. We should ask: What aspects of the old understanding of financial markets now seem compromised, perhaps simply wrong? What are the immediate intellectual consequences of this crisis for the political economy, and especially the political economy of Europe? Does this crisis provide us with opportunities as well as problems and, if so, what might those opportunities be?

A caveat: the reader who hopes that this chapter will provide definitive solutions to the practical problems raised by the crisis will be disappointed. Such a reader is asking the wrong question. There are real limitations on the extent to which an intellectual, operating in the abstract, should offer specific advice to responsible decision-makers. The world has plenty of armchair generals, Monday-morning quarterbacks and garrulous academics. Instead of second guesses, we should attempt to take advantage of critical distance to provide a cooler analysis and a longer view than is available to those in the trenches, perhaps accompanied by a few tentative and general suggestions by way of demonstrating a desire to be constructive. As a good friend often puts it, 'I am not in charge', and I offer my sympathies to those who are.

As I write, toward the end of 2009 , it is generally acknowledged that the recent economic crisis exposed serious weaknesses in the structure of European financial markets. To sketch the story in abstract terms: in 2008 and 2009, a number of bank crises required government intervention. ${ }^{1}$ Although the European Central Bank (ECB) made liquidity available to the central banks of Member States, kept interest rates low and

1 The European financial landscape is, as ever, dominated by banks. The financial crisis that presented across a variety of institutions in the United States was experienced in Europe as essentially a crisis in the banking sector. 
has been credited with avoiding panic in the financial markets, no European institution had the legal authority or the resources required to serve as lender of last resort to 'private' institutions. In the same vein, no European institution had the capacity, legal or otherwise, to resolve insolvent financial institutions, or to insure depositors, maintain trading positions, or otherwise intervene to stabilise financial markets. In Europe during the financial crisis, therefore, most government interventions were in fact, and of practical and legal necessity, interventions by Member States - i.e. national governments. In so intervening, generally spending taxpayer money, national governments tended to act on a national, as opposed to a European, basis.

A number of lessons can be learned from this story. Perhaps the first is that monetary integration, European Monetary Union (EMU), may not provide financial stability, even if currency stability is achieved. Using the traditional tools of central banking, the ECB maintained the stability of the Euro as a currency before and throughout the financial crisis. The crisis happened nonetheless. After the fact, it is obvious enough that radically overleveraged institutions may impose systemic risks, even if their balance sheets are reckoned in a then-sound currency. More theoretically, money supply cannot be divorced from the extension of credit, leverage; market confidence cannot be divorced from the volume, character and velocity of trading. Banks and other financial institutions, however, not just central banks, extend credit and trade. Financial stability, therefore, requires not only sound money, a well-managed Euro, but prudent institutions to manage such money. To put matters gently, many European banks were imprudent.

A complication: in (overly positivist legal) theory, much banking regulation is harmoniously conceived at the European level, and implemented at the Member State level. So we may speak of European banking regulation. Supervision and resolution, however, are matters of Member State competence. But positivists tend to forget that law on the books is not what matters to sound policy; law cannot be understood apart from its social context, including its implementation. (This is especially true in the case of financial regulation. For example, US securities law is hardly to be understood by reading the statutes.) At this level of analysis, the once-easy claim that European banking regulation is fairly harmonised begs more than a raised eyebrow: actual Member State implementation of regulation, deeply intertwined with supervision, meant that political constraints (regulation in the broad sense used in US policy discourse) on European banks in the years leading up to the crisis varied 
considerably from country to country. In short, integrated European banking law leading into the crisis was partially achieved at best, and further fragmented by essentially national responses to the crisis.

At the same time, European banks often operate across borders, indeed have been encouraged to operate across borders in furtherance of European financial market integration. More specifically, transnational financial operations have been intentionally facilitated by the single currency. ${ }^{2}$ Access to the European market has meant that the banks of relatively small countries might have considerable operations in much larger economies. Failure of a big bank based in a small country is unlikely to be successfully resolved by the government of that country. Putting this all together, it might be said that transnational systemic risk was facilitated, if not caused, by the emergence of a more integrated European financial market, coupled with the failure of fundamentally national oversight regimes. ${ }^{3}$ The desire for financial stability, especially when coupled with monetary integration, would thus seem to imply not only regulatory reform, but financial law that was more integrated in fact, not merely in bureaucratic wish.

However, as noted above, supervision and resolution of financial institutions in Europe are largely matters of Member State competence. Member States guard their jurisdiction over such issues especially jealously because the fisc of, and the asset values within, each Member State are affected. As a result, and as demonstrated in the events of 2008, responses to institutional crisis tend to be national and therefore both partial and fragmented. Conversely, truly integrating European financial policy would require at least substantial burden-sharing for the supervision and especially resolution of financial institutions. A contrast is often drawn with the United States, where the Federal Reserve and the Treasury, operating on the Federal level, not only supervise, but also have the resources to intervene directly. No analogue exists on the European level, and it is difficult imagining European institutions acquiring such competences or resources within the foreseeable future. So, to generalise, the 2008 crisis demonstrates what has been suspected for some time: true

2 This point should not be overdone. Contagion often occurs across currencies, and did in this crisis. Rephrased, a single currency may encourage cross-border operations, but is hardly a sine qua non for cross-border problems.

${ }^{3}$ It should immediately be noted that this problem is not unique to Europe; one might say much the same thing on a global level with regard to Lehman Brothers - i.e. nationai regulatory failure allowed a transnational systemic risk to be realised. 
European monetary union is stymied, or at least profoundly constrained, by the lack of European fiscal integration. ${ }^{4}$

In the same vein, although existing national regulation of financial institutions is derived from European directives, and such regulation has been shown to be in need of reform (both weaker and less well integrated than one might have hoped, when times were good), substantial new European directives do not seem likely. Recent political developments such as the French and Dutch 'no' to the proposed European Constitution; the exceedingly difficult passage of the Lisbon Treaty; and the German Constitutional Court's suggestion that no further derogation to the EU could be allowed under German law - strongly suggest that financial institutions will be governed more on the national, rather than the European, level for the foreseeable future. And, as has also been suggested, since the Union does not have the power to tax and does not look to acquire the power to tax anytime soon, only Member States (indeed, only large Member States) possess the ready cash required to intervene in a banking crisis. Such interventions, however, tend to fragment, rather than integrate, the European financial system. The true integration of European financial law, therefore, seems to be both more necessary, and much farther away, than many people thought even recently.

In a draft paper that has attracted considerable attention in policy circles, Dirk Schoenmaker elegantly if very schematically states this problematic as the 'trilemma' of financial stability: 'a stable financial system, an integrated [European] financial system, and national financial autonomy are incompatible. Any two of the three objectives can be combined but not all three; one has to give. ${ }^{5}$ In the crux of the paper, Schoenmaker argues that in an integrated financial market, defined as a market in which important institutions have substantial cross-border operations, a national regulator may rationally but inefficiently decide not to save some systemically important financial institutions, because the national government does not gain from rescuing banking operations conducted in foreign countries. Exhibit $A$ for this claim would be the failure of Fortis.

4 See, generally, R. Lastra, Legal Foundations of International Monetary Stability (Oxford University Press, 2006), chapter 10.

5 D. Schoenmaker, 'The Trilemma of Financial Stability', draft available at ssrn.com/ abstract $=1340395$. The trilemma image is well established in monetary policy, and Schoenmaker and others have used the image to make versions of this argument for some time. See Lastra, Legal Foundations, supra n. 4, and the sources cited therein. 
Schoenmaker assumes (perhaps slighting the long Dutch tradition of fiscal independence?) that financial stability is self-evidently the cardinal virtue: the trilemma is thus resolved into a conflict between an integrated European financial market, on the one hand, and national control over financial institutions (and their resolution) on the other. From a European (as opposed to a national) political perspective, and from a relatively orthodox liberal economic perspective, both the course of history and the national order favour expansive and integrated financial markets, and so we learn that supervision is 'still' done at the national level, By now, we are on familiar ground. The trilemma is not difficult as an intellectual matter: the desire for financial stability requires integration of regulation, oversight and even resolution on the European level, founded on a degree of fiscal integration, and national financial autonomy has to give way. As a political matter, however, European progress is frustrated, here as elsewhere, by the parochial interests of national governments. The European financial markets, then, seem doomed to some messy combination of halting integration/national fragmentation, coupled with structurally inadequate supervision (and lagging regulation), resulting in financial instability and associated disadvantages in the real economy.

Are matters really as gloomy as the trilemma so logically implies? If not, what is wrong with the broadly shared assessment of the situation of European financial markets and their regulation that the trilemma so elegantly articulates? In short, how should European policy-makers confront the trilemma?

Two implicit aspects of the problematic seem analytically significant to me. First, the trilemma has a complex relationship with liberal economic thought. On the one hand, the choices highlighted by the trilemma were long obscured, in Europe and elsewhere, by a liberal economic orthodoxy that did a fair job of accounting for relatively stable markets. On the other hand, the trilemma is logically dependent on the same liberal economic orthodoxy, which raises issues if one no longer believes. ${ }^{6}$

Second, both the trilemma and what I take to be the dominant understanding of the European project are informed by a particular political imagination that associates scale with centralisation, centralisation with rationalisation and rationalisation with progress. As an intellectual

6 See, generally, D. A. Westbrook, Out of Crisis. Rethinking Our Financial Markets (Boulder, CO: Paradigm Publishers, 2009). 
matter, I do not think this is correct - to quip, it is to mistake the history of France for the history of globalisation, and also for the deep structure of the European project. ${ }^{7}$ But whether or not the imagination of politics dominant in Europe made sense at one time, or even makes sense in the abstract, this imagination does a poor job addressing the problems of economic integration across jurisdictions, either globally or in Europe, and either now or for the foreseeable future. Neither nation-states nor Member States are going to surrender jurisdiction to a government whose scale matches that of the economy.

Consequently, we must find ways to think politically about financial market regulation under conditions of decentralisation. Fortunately, European traditions of law and politics apart from the administrative centralisation associated with the rise of the modern nation-State, and another of Vagts' areas, American commercial law, have things to teach about creating integrated and reasonably well-governed markets across jurisdictions.

In times of relative economic stability, it is easy enough to understand markets as ordinarily efficient and largely self-correcting. In such times, regulation and supervision of banks and most other key financial institutions remain necessary (only a particularly ideological American might think otherwise), but attract relatively little attention (bank failure has not been so interesting for generations). And thus for many years in Europe, banks were encouraged to develop their risk management models; monetary union proceeded without regulatory integration, and that seemed not only politically necessary but untroubling; and Member State governments were left to regulate and supervise the institutions established within their jurisdictions. Moreover, variances among Member State regulation were seen as an impediment to the integration and expansion of financial markets - that is, to cost money and be inefficient, just as variances among regulatory regimes for other goods and services were traditionally thought to be at odds with the achievement of a true single market. So the project was to work national regulatory barriers down, gradually shifting competence to European institutions and, through the Second Banking Directive and otherwise, to encourage financial institutions established in one Member State to do business in others. During these years, the European financial order was relatively stable - a bit sluggish, perhaps, but stable.

7 See, generally, D. A. Westbrook, City of Gold. An Apology for Global Capitalism in a Time of Discontent (New York and London: Routledge, 2003). 
Under such circumstances, the trilemma's conflicts, among European and national jurisdictions and financial stability, are hardly apparent. It is only when financial markets are unstable, systemically important institutions are failing and massive and decisive government intervention is required, quickly, that the trilemma's questions - 'which governments can effectively do what, for whom'? - arise. Suddenly national regulatory, supervisory and fiscal authorities are seen as not merely anachronisms, but absolutely essential to avoid panic. A general sense of broadly available efficiencies, fostering highly leveraged operations with tight margins arbitraged across great distances, all very well oiled, that for years made 'European' solutions seem so sensible, can be and was quickly replaced by sudden recognition of widespread mispricing, radical uncertainty, especially about counterparty risk, acute problems of illiquidity even among fundamentally solvent institutions, the insolvency of major institutions, negotiations held over weekends, the need for effective power and the indispensability of national institutions. This is so even if national action presents prisoner's dilemma problems - that is, when a coordinated response would have, in theory, been more efficient.

Although the trilemma is most evident when pricing fails, and the intellectual edifice of liberal economics is rumoured to be collapsing, the trilemma itself is very much a product of liberal political economy. In the traditional push toward 'rigour', the trilemma assumes governments that are able to assess the relative costs of different courses of action, and that act in rational and self-interested fashion upon their assessments. Suffice it to say that such rationality does not describe the action of any of the governments going into the 2008 crisis; it is precisely the risk management edifice that failed. Thus, while it is true that many Member State governments acted in the national, rather than the European, interest, it is a stretch to say that such action was particularly rational, or that any of the governments could have had more than the haziest sense of what the ramifications of various courses of action might have been.

The trilemma reflects its roots in liberal economics in another way: government action is thought of as essentially distinct from marketplace action - i.e. politics are distinct from markets, and the purpose of politics is to facilitate markets. The traditional bifurcation between markets and politics is especially implausible in times of financial crisis, when 'private' institutions are supported by direct injections of tax dollars. More generally, the financial markets are hardly independent of political processes, and so the assumption that financial stability is a cardinal virtue for constitutional thought is unwarranted. The analytic question for 
political economy is: How do those aspects of social life that we understand as 'political' interpenetrate those aspects of life that we understand as 'economic'? 'The normative question for political economy is: 'What sort of markets do we, as a society, wish to construct'? Such questions cannot be asked from within liberal orthodoxy, which distinguishes too strongly between government and market, public and private interest. In short, much contemporary analysis of the situation of the European financial structure is subtly dependent on the beleaguered orthodoxies of liberal economics; it hardly needs saying that the same intellectual dependency hampers policy thought in the United States.

As sketchy as the foregoing has been, my next point is more speculative still. It seems that a second implicit, and vital, aspect of much contemporary European thinking about financial regulation is a particular imagination of politics that silently structures, indeed dominates, policy thought. Political action is conceived in terms of jurisdiction to regulate, and is essentially exclusive. Thus, by way of example, the trilemma assumes that if we wish to have good markets (financial stability), a choice must be made regarding jurisdiction over those markets - i.e. a choice between European and Member State regulators (here again, using 'regulators' in the broadest sense). Moreover, the choice for national rather than European law that appears to be politically necessary at the moment is understood to be somewhat retrograde; progress is understood to be the centralisation of vital politics (monetary, eventually diplomatic and perhaps military) within dedicated European institutions. From this perspective, which perhaps should be associated with former European Commission chief Jacques Delors, political progress in Europe essentially maps that of the modern administrative State: a linear evolution towards ever-more rational, centralised and bureaucratic forms of social life.

It need not be, indeed was not always, thus. For many years, the European project was publicly and privately said to be 'sui generis'. The European project was understood, except perhaps by some of the English, to be more than trade and different from the nation, to be some sort of new politics. The terms and form of that politics, however, were admittedly emergent, as yet unclear, hence sui generis. This lack of definition was fruitful: 'Europe' provided just enough of a horizon to organise significant political thought and action for decades. At least to this friendly outside observer, at some point during the 1990s - after the Single European Act (SEA), perhaps with Maastricht, certainly by EMU - the European imaginary shifted. Although the phrase 
'United States of Europe' remained a bit vulgar, used pejoratively by Eurosceptics, many people in fact started conceiving of Europe as a very diverse, continental, republican, commercial polity - i.e. much like the United States. And such polities, as the United States has demonstrated, need constitutions. ${ }^{8}$ From within this perspective, the 'political' requirement that financial regulation (in practice if not theory) and intervention and resolution (in theory and practice) be conducted on the Member State level is seen as a setback for the European project.

Conversely, from within this same perspective, progress is understood to be the transferral of politics from areas of smaller geographical scope to areas of larger geographical scope; from 'lower' to 'higher' 'levels' of government; and from the Member States to the European institutions. So the trilemma strongly implies that moving the supervision and regulation of financial institutions to the European level will generate financial stability.

A word of intellectual caution is in order here. While constitutional arguments always maintain that better politics will flow from the establishment of a better structure, real life tends to be messier. Assuming perhaps heroically that large Member States do not capture regulatory processes, making the law of financial institutions an essentially European affair may remove the structural tendency toward fragmentation demonstrated during this crisis. Merely federalising financial law, however, hardly guarantees its effectiveness. Although the situation in the United States is complicated, it is generally thought that the Federal Reserve did not acquit itself very well in the years leading into the crisis, and numerous mistakes have been made in the management of the crisis itself. And as has long been noted both in Europe and especially in the United States, centralisation of power raises its own dangers.

More generally, the failure to realise a European financial law is only a setback if the European financial order should be highly centralised. But it would be unfortunate if the destiny of Europe was to be a highly centralised State, not least because that destiny will be frustrated for the foreseeable future - that is, European politics will be understood as a failure. Even assuming that it would be a good idea to integrate financial regulation, supervision, resolution and presumably a degree of taxation

${ }^{8}$ It can be said that the centralising tendency was always balanced by the countervailing idea of subsidiarity. True enough, but as the name suggests, 'subsidiarity' is a derivative concept, an argument against the presumption of centralisation. Conversely, subsidiarity is hardly a strong argument for politics; it is not constitutive. 
on the European level, such integration is not going to happen soon. And, it should be said, the identical argument could be made on a global level: the existence of an integrated global economy requires global regulatory structures - i.e., not just the current flaccid collection of institutions and precatory laws, but a real global government. I am not holding my breath.

But suppose the issue is not merely one of noble (European) ideals frustrated by harsh (national) political realities? Perhaps rationalising centralisation is not, even in principle, the only horizon for politics, including the politics of financial regulation? Surely there is much to be said for nations and other polities, even in an age of economic and other integrations? And should the possibility that Europe represents a new form of political life, something that does not appear very often on the world stage, be given up quite so easily?

Visiting the United States, Tocqueville at first wondered at a large country that seemed, to an astounding degree, to function without government. Upon further observation and reflection, Tocqueville realised that he had overlooked the prevalence of local administrations, and had mistaken the absence of centralised administration for a lack of governance. Clearly society in the United States governed itself, indeed constituted a union, implying a substantial degree of centralisation of some sort, even if not the hub and scope organisation of statutory authority radiating out from the capital with which he was familiar. So Tocqueville famously distinguished between 'administrative centralisation' and 'governmental centralisation'. 'What Tocqueville meant by 'administrative centralisation' is clear enough, exemplified by the France of his day and ours. What he meant by 'governmental centralisation' is more difficult to say: sometimes the phrase is associated with the (national) legislature (that does not have administrative powers under the US Constitution); sometimes with democracy writ large, and sometimes with the sources of strength and unity within a society. Clearly, however, Tocqueville was on to something important: the United States, for all its millions of people and vast spaces and enormous tangle of jurisdictions, is a very unified polity and, critically for present purposes, an integrated financial market. This unification is not a result of jurisdictional unity, for the simple reason that, even after the Civil War and the New Deal, there is no jurisdictional unity. The principles of unity must be

${ }^{9}$ My thanks to Nicolas Veron for raising Toqueville's distinction vis-d-vis my argument. 
found at a deeper, societal or cultural, level. And yet such unity is normative, regulatory, governmental.

My thought is that governmental centralisation could be a key way to reconceptualise financial policy - indeed, politics more generally - in Europe, thereby helping to free political discourse from the coils of the jurisdictional fight articulated by the trilemma. And if we look at European history more broadly, we see a great deal of political life without administrative centralisation, that is, across a wealth of jurisdictions. Germany and Italy were political contexts for centuries before they had anything resembling centralised administrations. Since the Middle Ages, the lex mercatoria has made commerce possible among traders from many different countries. And for generations the Roman law was 'the' law virtually everywhere in Europe, quite independent of whether or not, or how, it was the positive law in this or that place. In short, history teaches that political economy does not require the degree of unity of authority that is so often presumed.

It might be said, however, that this is an essentially medieval view, that the story of modernity is the subordination of the nobles to the king, of local authority to central administration, of ideal laws and customary trading patterns to positive laws and regulated markets. I disagree. Moving from history to comparison, the United States demonstrates a tightly integrated, highly modern, market - indeed, the paradigmatic diversified economy - and a great number of jurisdictions, and conversely, a notable shortfall in formal administrative centralisation and attendant positive law. The degree of decentralisation in the United States is, on reflection, quite astonishing. Consider the following:

- Property, contract and tort (delict, which stands in lieu of a fair degree of regulation) are all overwhelmingly State law.

- Corporations are State law; there is no national company law.

- Banks may be chartered on either the State or the Federal level. Both individual States and the Federal government regulate banks and similar institutions.

- Insurance companies are regulated almost exclusively by the States.

- Securities law is mostly Federal law, but States retain the authority to regulate securities.

- Criminal law, including matters such as fraud, is both Federal and State.

The point here is not that the United States has it 'right'. Regulations in the United States, like anyplace else, are variously successful, and this 
chapter is not long enough for thoughtful suggestions about particular aspects of US financial regulation that might be worth European attention, by way of either adoption or avoidance. Moreover, it should not be denied that the multiplicity of jurisdictions in the United States can create waste and confusion. It is quite possible that insurance, for example, should be regulated on the Federal, and not the State, level. Those things said, the point here is that the United States demonstrates that a highly integrated financial market can be created among multiple jurisdictions. This fact provides a modicum of hope, because it means that, in a global context of multiple nation-states, or in a European context of multiple Member States, as in a Federal context, politics need not be understood to be coterminous with jurisdiction - i.e. political discourse is not delimited by the authority of the modern administrative nationstate. Therefore, the impossibility of achieving a politics coterminous with jurisdiction does not necessarily imply that political efforts are doomed. More specifically, the fact that Member States are not going to cede supervisory, much less resolution, powers over their financial institutions to European institutions does not mean that European financial policy is at an end. More hopefully still, the realisation that politics may transcend jurisdiction may help renew the spirit of European political invention.

Just suppose that European politics comes to understand itself along the lines suggested here, in terms of governmental centralisation, of a European culture of government. What would such an understanding of European politics mean for policy? What specific programmes should European institutions adopt if they intend to improve financial regulation, even while jurisdiction remains national?

In the absence of authority to proceed positively on the European level, perforce modest starts on European financial reform have been made through international colleges of financial institution supervisors, and through enthusiasm for 'living wills' and other industry initiatives. One might hope that such efforts contribute to a more European, and wiser, collective understanding of financial regulation. At the same time, it should be rather dourly noted that such measures were not legally binding, and were not strong enough to ensure cooperation during the 2008 crisis, raising the question of whether the improved versions currently under discussion will fare any better in a future crisis. More broadly, it should be remembered that meetings among upper-level bureaucrats, trained internationally, in disciplines formed internationally, are hardly new. European elites have generally had international 
experience and, within limitations, a 'European' perspective. And during the 2008 crisis, such elites acted in national as opposed to European fashion.

So how might a deeper European governmental centralisation be pursued, while respecting the prerogatives of Member State authorities? Two obvious places to start would be education and law, and, fortuitously for the purpose of honouring Vagts, the combination of education and law: legal education. As Tocqueville recognised, and as remains true, Americans exhibit a surprising degree of uniformity in all sorts of regards, despite the land's vast spaces, and the various cultural backgrounds and beliefs of her people. In particular, Americans share beliefs and assumptions about the institutions of commercial society: property, contract and the like. (Americans often and erroneously think that their beliefs about such institutions are natural.) So, Tocqueville also recognised, one of the most important vectors for governmental centralisation in the United States is law. This has become more true since Tocqueville's day, with the development of the modern law school. While the law taught in law schools is largely (not exclusively) State law, it is not the law of any given State - any basic casebook contains laws from multiple jurisdictions at different times, with no direct or authoritative bearing upon one another. Rather than the positive law of any given jurisdiction, what is taught is legal culture in a general American sense. As a result, people trained at Harvard Law School, in the hardly economically dominant State of Massachusetts, can and do practice American (not US) law all over the United States, and indeed around the world.

This is not to say that positive law is unimportant. But, in a precedential system, with fifty States, a Federal government and countless regulators, practitioners are expected to look up the positive law of the relevant jurisdiction, so that they are absolutely current, and can cite the immediately responsible authority. Legal thought, and policy discourse more generally, tends to happen on the cultural plane, rather than that of positive law.

The national legal culture and State jurisdiction are often understood in complementary, mutually reinforcing, fashion. Notably, the licensing of lawyers (and other professionals) is usually a State function. Typically, State bar associations administer an exam. A candidate for the bar is only allowed to sit for the exam, however, if she has graduated from an accredited law school. And law schools are accredited by the American Bar Association (ABA) - i.e. on a national basis. Moreover, in most States, the first day of the exam is the so-called Multistate exam - i.e. 
an exam written by the $\mathrm{ABA}$ and based on the national understanding of fundamental areas of law, rather than on the particular rules of a given State.

Surely it would be possible to imagine European financial politics along structurally similar lines - as an essentially cultural discourse that informed the thinking of more localised authorities and, as importantly, market participants. The impasse ostensibly revealed by the 2008 financial crisis is an artifact of certain unnecessary assumptions about politics rather than an intractable flaw in the European constitution. But while the political structure of Europe does not preclude serious rethinking of European financial markets, one must not expect too much from mere constitutional reconceptualisations. A lively continental discourse on financial policy, held in an integrated market stretching across any number of jurisdictions, has not always kept the United States from folly, notably in the 2008 crisis. Financial policy, like politics more generally, can be expected to remain difficult. 